\title{
ANALISIS KESALAHAN EJAAN \\ PADA MAKALAH MAHASISWA PRODI TEKNIK MESIN FAKULTAS TEKNIK UNIVERSITAS MUHAMMADIYAH TANGERANG
}

\author{
Asfitri Hayati \\ Universitas Muhammadiyah Tangerang \\ Email: asfitrih@gmail.com
}

\begin{abstract}
ABSTRAK
Penelitian ini bertujuan untuk mengetahui kesalahan ejaan pada makalah mahasiswa prodi teknik mesin. Penelitian ini merupakan penelitian kualitatif dengan metode deskriptif. Berdasarkan hasil analisis data penelitian, ditemukan beberapa kesalahan bentuk Kesalahan ejaan pada tugas makalah mahasiswa terletak pada (1) kesalahan pemakaian huruf kapital ditemukan sebanyak 31, (2) kesalahan terletak pada ketidakbakuan pilihan kata ditemukan sebanyak 37, (3) kesalahan terletak pada ketidaktepatan pilihan kata ditemukian sebanyak 52, (4) kesalahan terletak pada pemakaian tanda baca ditemukan sebanyak 43. Pada penulisan tanda baca, terdapat 43 kesalahan penggunaan tanda baca, meliputi 35 kesalahan tanda baca titik (.), 8 kesalahan tanda baca titik dua (:). Kesalahan terbesar yaitu terletak pada Ketidaktepatan Pemilihan kata yang berjumlah $32 \%$ tingkat frekuensi 0,96 dari total kesalahan. Kesalahan terletak pada pemakaian huruf kapital sebesar $19 \%$ frekuensi 0,62, kesalahan terletak pada ketidakbakuan pilihan kata sebesar $23 \%$ tingkat frekuensi 0,74 , dan kesalahan terletak pada pemakaian tanda baca sebesar $26 \%$ tingkat frekuensi 0,86.
\end{abstract}

Kata kunci: kesalahan ejaan, makalah, mahasiswa.

\section{A. PENDAhULUAN}

Bahasa berperanan sangat penting dalam kehidupan sehari-hari karena tanpa bahasa kita tidak dapat berkomunikasi antar manusia. Bahasa merupakan sebuah kemampuan yang dimiliki manusia dalam berkomunikasi dengan sesama manusia. Bahasa adalah sebuah sistem yang dibentuk oleh sejumlah komponen yang berpola secara tetap dan dapat dikaidahkan. Sistem bahasa berupa lambang-lambang bunyi setiap lambang bahasa melambangkan sesuatu yang disebut makna atau konsep. Bahasa terdiri atas kata-kata atau kumpulan kata yang mengandung makna. Bahasa menggunakan lambang sebagai objek yang mewakili kata atau kosa kata.

Pada waktu kita berbicara atau menulis, kata-kata yang kita ucapkan atau kita tulis tidak tersusun begitu saja, melainkan mengikuti aturan yang ada. Untuk mengungkapkan gagasan, pikiran atau perasaan, kita harus memilih kata-kata yang tepat dan menyusun kata-kata itu sesuai dengan aturan bahasa. Kesepakatan dalam menggunakan bahasa atau pedoman bahasa 
disebut dengan tata kebahasaan. Pemakaian bahasa dalam farum formal diharuskan menggunakan pedoma bahasa.

Apabila pedoman berbahasa tidak digunakan maka akan terjadi suatu kesalahan berbahasa. Kesalahan berbahasa dapat mempengaruhi makna bahasa. Analisis kesalahan berbahasa merupakan suatu aktivitas dalam mengidentifikasi, mengklarifikasi, dan mengevaluasi suatu kesalahan dalam berbahasa. Analisis kesalahan berbahasa dipandang sebagai suatu aktivitas yang dilakukan oleh peneliti, dosen bahasa Indonesia maupun guru bahasa Indonesia dalam mengidentifikasi kesalahan berbahasa dan mengklarifikasi kesalahan berbahasa. Kesalahan berbahasa adalah penyimpangan-penyimpang yang dilakuan oleh seseorang secara sistematis dankonsisten.

Pengajaran bahasa Indonesia di perguruan tinggi dilakukan untuk menguatkan penguasaan bahasa Indonesia dalam pemakaian bahasa Indonesia yang baik dan benar secara lisan maupun tulisan. Pengajaran bahasa Indonesia ini dianggap penting karena mahasiswa dianggap dekat dengan penggunaan bahasa Indonesia dalam kegiatan ilmiah. Mahasiswa juga dianggap memiliki peranan penting dalam menyebarkan penguasaan bahasa Indonesia yang baik dan benar (Hermawan, 2019:35-36). Mahasiswa sebagai calon generasi penerus dianggap sebagai agen penyebar keterampilan berbahasa yang baik dan benar. Analisis kesalahan berbahasa pada makalah mahasiswa menjadi suatu permasalahan yang menarik untuk dikaji. Banyak dosen yang menugaskan mahasiswa untuk membuat makalah mengenai sebuah tema tertentu dan sesuai dengan mata kuliah masing-masing. Dosen memberikan tugas kepada mahasiswa untuk membuat makalah dengan tujuan melatih mahasiswa menulis sesuai dengan kaidah bahasa yang telah disempurnakan, karena makalah mahasiswa merupakan jenis karya tulis. Maka, tujuan penelitian ini yaitu untuk mengetahui kesalahan berbahasa pada makalah mahasiswa prodi teknik mesin fakultas teknik Universitas Muhammadiyah Tangerang.

\section{B. KAJIAN PUSTAKA}

Ejaan merupakan keseluruhan dari peraturan tentang bagaimana menggambarkan tentang lambang - lambang bunyi ujaran. Ejaan juga mengatur tentang bagaimana interelasi antara lambang - lambang tersebut ke dalam suatu bahasa. Ejaan yang Disempurnakan atau EYD merupakan sistem ejaan yang resmi di Indonesia. EYD mengatur tentang pemakaian huruf, penulisan unsur serapan, penulisan kata, dan penggunaan tanda baca. Ejaan adalah keseluruhan peraturan bagaimana melambangkan bunyi ujaran dan bagaimana antarhubungan antara lambang-lambang itu (pemisahan dan penggambungannya dalam suatu bahasa). Selain 
itu, ejaaan merupakan keseluruhan peraturan tentang perlambangan bunyi ujaran dan hubungan antara lambang-lambang itu (Kosasih, 2012:139).

Kesalahan berbahasa merupakan kesalahan dalam berbahasa secara lisan maupun tulisan yang dipengaruhi oleh faktor-faktor penentu berkomunikasi dan kaidah bahasa. Kesalahan berbahasa itu bisa terjadi disebabkan oleh kemampuan pemahaman mahasiswa atau pembelajar bahasa. Artinya, mahasiswa memang belum memahami sistem bahasa yang digunakan. Kesalahan biasanya terjadi secara sistematis. Kesalahan jenis ini dapat berlangsung lama bila tidak diperbaiki. Perbaikannya biasanya dilakukan oleh dosen/guru. Misalnya, melalui pengajaran remidial, pelatihan, praktik, dan sebagainya. Baradja dalam Turistiani, memberikan penjelasan bahwa kesalahan berbahasa adalah terjadinya penyimpangan kaidah dalam tindak berbahasa, baik secara lisan maupuin tertulis. Penyimpangan itu dibedakan atas kekeliruan (mistake) dan kesalahan (error). Kekeliruan adalah penyimpangan pemakaian bahasa yang terjadi tidak secara sistematis. Kekeliruan mengacu pada language performance yang terjadi karena keterbatasan ingatan, mengeja dalam lafal, keseleo lidah, tekanan emosional, dan sebagainya. Sebaliknya, kesalahan adalah penyimpangan dalam pemakaian bahasa yang terjadi secara sistematis. Kesalahan bersifat konsisten dasn menggambarkan kemampuan si penulis pada tahap tertentu.

Makalah merupakan salah satu jenis karya tulis ilmiah yang digunakan dalam perkuliahan (Dalman, 2018:36). Makalah merupakan sebuah karya tulis ilmiah mengenai suatu topik tertentu yang tercakup dalam ruang lingkup pengetahuan. Suatu makalah memiliki sistematika yang terbagi menjadi empat bagian, yakni pendahuluan, studi kepustakaan, pembahasan dan simpulan atau penutup. Selain itu menurut Achmad dan Alex (2016:65) bahwa makalah merupakan karya tulis yang membahasa mengenai topik atau permasalahan tertentu yang ditulis secara sistematis, relevan, jelas, efektif, dan benar yang dikembangkan dengan analisis yang logis dan objektif.

\section{METODE PENELITIAN}

Penelitian ini merupakan penelitian kualitatif dengan metode deskriptif. Jenis penelitian dengan metode tersebut digunakan untuk mengungkapkan kesalahan pemakaian huruf, ketidakbakuan pemilihan kata, ketidaktepatan pemilihan kata, penulisan tanda baca. Penelitian ini dilakukan dengan menggunakan pendekatan kualitatif yang termasuk dalam penelitian kebahasaan. Boydan dan Taylor (dalam Moleong, 2005) mengatakan bahwa pendekatan kualitatif merupakan prosedur penelitian yang menghasilkan data deskriptif berupa kata kata tertulis atau lisan dari orang-orang dan perilaku yang dapat diamati. 
Objek penelitian ini adalah ejaan dalam tugas makalah mahasiswa semester I Reguler B1 dan B2 yang berjumlah 50 makalah. Teknik pengumpulan data yaitu melalui teknik baca, yaitu membaca makalah yang telah dipilih dengan cermat dan berulang. Selain teknik baca, penulis juga menggunakan teknik catat untuk mencatat kesalahan-kesalahan yang ditemukan dengan bantuan kartu data dan dikategorikan dalam kriteria kesalahan yang telah ditentukan untuk kemudian dianalisis dan dideskripsikan. Taknik catat ini digunakan untuk mengungkapkan suatu permasalahan yang terdapat dalam suatu bacaan atau wacana.

\section{HASIL PENELITIAN DAN PEMBAHASAN}

Dari hasil analisis diperoleh kesalahan sebanyak 163 kasus kesalahan, meliputi: (1) pemakaian huruf, (2) Ketidakbakuan pemilihan kata, (3) ketidaktepatan pemilihan kata, (4) penulisan tanda baca.

\section{Kesalahan Pemakaian Huruf Kapital}

Kesalahan pertama pemakaian huruf kapital terdapat pada penulisan kata tuhan yang maha esa. Seharusnya dengan huruf kapital. Apabila kata itu digunakan untuk Tuhan, harus ditulis dengan huruf kapital Tuhan jadi penulisan kata yang benar adalah Yang Maha Esa karena tunggal.

Kesalahan kedua pemakaian huruf kapital terdapat pada penulisan kata Allah swt yang maha pengasih dan penyanyang yang seharusnya dengan huruf kapital. Apabila kata itu digunakan untuk Tuhan, harus ditulis dengan huruf besar Tuhan jadi penulisan kata yang benar adalah Allah SWT Yang Maha Pengasih dan Penyanyang, karena merupakan induk kalimat.

Kesalahan ketiga pemakaian huruf kapital adalah pada penulisan menambah pengetahuan dan pengalaman pembaca, Untuk kedepannya dapat memperbaiki bentuk. Seharusnya pada kata untuk dengan huruf kecil.

Kesalahan keempat pemakaian huruf kapital adalah pada penulisan Bab pendahuluan. Seharusnya pada kata ditulis dengan huruf kapital semua karena merupakan induk kalimat yang memberikan penjelasan atau gambaran. jadi penulisan yang benar adalah BAB I

\section{PENDAHULUAN.}

Kesalahan kelima pemakaian huruf kapital adalah pada penulisan nama fakultas fakultas teknik mesin. Seharusnya penulisan kata fakutas ditulis dengan huruf kapital, karena merupakan nama dari sebuah instnasi. Jadi penulisan yang benar adalah Fakultas Teknik Mesin atau boleh ditulis dengan hruf kapital semua asalkan tidak keluar dari konteks.

Kesalahan keenam terdapat pada penulisan nama Aditya Apria Fadilliyah. Kesalahan dalam penulisan ejaan menyebabkan dalam Ejaan yang Disempurnakan, huruf pertama unsur- 
unsur nama orang ditulis menggunakan huruf kapital. Penulisan yang benar sesuai dengan Ejaan adalahan sebagai berikut. Aditrya Aprian Fadiliyah.

Kesalahan ke tujun terdapat kesalahan pemkaian huruf kapital pada penulisan kekerasan terhadap anak, seharusnya setiap judul harus menggunakan huruf kapital di awal kalimat. Penulisan yang benar adalah Kekerasan Terhadap Anak.

2. Kesalahan ketidaktepatan pemilihan kata

Kesalahan ketidaktepatan pemilihan kata dalam pemilihan kata. Kesalahan pertama, "Kami juga mengucapkan terima kasih kepada semua pihak yang telah berkontribusi untuk tersajinya makalah ini." Kesalahan ketidaktepatan pemilihan kata terdapat pada kalimat tersajinya arti dari tersaji adalah tersedia, terhidang contoh: 'ibarat makanan sudah tersaji, tinggal makan saja semua. Jadi ketepatan pemilihan kata seharusnya kata tersajinya yang tepat adalah terselesainya makalah ini.

Kesalahan kedua, "Yang mana para teman-teman sudah membantu saya dalam menyelesaikan tugas dan Dosen mata kuliah.” Berdasarkan kalimat tersebut merupakan kalimat menjadi tidak efektif karena diawali dengan kata yang mana. Kata yang mana sebenarnya tidak menduduki fungsi dalam kalimat itu, sehingga penggunaannya dalam kalimat itu lebih baik dihilangkan. Selain itu, penulisan kata yang seharusnya tidak menggnakan huruf besar karena merupakan kata hubung pemilihan kata kurang tepat dalam melengkapi kalimat.

\section{Kesalahan Ketidakbakuan Pemilihan Kata}

Kesalahan pertama, kalimat "Aku bercita2 ingin menjadi dosen dan membahagiakan orang tua." Ketidakbakuan pada kalimat pertama terletak pada penulisan kata ulang. Pada kalimat itu, kata ulang ditulis dengan menggunakan angka 2 sehingga menyebabkan kalimat itu tidak baku. Bentuk ulang yang benar adalah ditulis secara lengkap dengan menggunakan tanda hubung. Jadi, bentuk baku dari kalimat itu sebagai berikut. Aku bercita-cita ingin menjadi dosen dan membahagiakan orang tua.

Kesalahan kedua, pada kalimat "Kesalahandata berikut adalah Mereka menilai bahwa mutu maupun kwalitas pendidikan di daerah satu dengan daerahnyapun berbeda." Penulisan kata tidak baku karena terdapat kesalahan dalam penulisan kata. Kata kwalitas tidak baku, bentuk bakunya adalah kualitas. Selain itu, penambahan partikel pun pada kata daerahnyapun seharusnya ditulis terpisah dari kata yang mendahuluinya. Penulisan kalimat diubah menjadi bentuk baku menjadi sebagai berikut. Mereka menilai bahwa mutu maupun kualitas pendidikan di daerah satu dengan daerahnya pun berbeda. 
Kesalahan ketiga, terdapat pada kalimat "Setelah saya sudah mengetahui tentang kepribadiannya dan sebaliknya dan kita sudah menganggap berteman dan sudah bisa dianggap seperti sahabat dekat." Data ketidakbakuan pada kalimat di atas disebabkan oleh pemborosan penggunaan kata dan. Pemborosan dalam penggunaan kata dan dan penempatannya dalam kalimat yang kurang tepat mengakibatkan kalimat itu menjadi tidak baku. Bentuk baku dari kalimat adalah Setelah saya mengetahui kepribadiannya begitu pun sebaliknya, akhirnya kami berteman dan kami dapat dianggap seperti sahabat dekat. .

Kesalahan keempat, pada kata "Walaupun dan tetapi." Kata penghubung itu seharusnya digunakan salah satu saja. Selain itu, penggunaan kata berhenti pada kalimat itu kurang sesuai. Kata berhenti seharusnya diganti dengan kata berakhir. Kata berhenti dan berakhir adalah dua buah kata yang bersinonim, tetapi dalam penempatannya pada kalimat tidak dapat saling menggantikan. Jika diperbaiki menjadi kalimat baku, maka kalimat itu menjadi Walaupun kami berbeda sekolah, persahabatan kami tidak berakhir.

4. Kesalahan pada Tanda baca

Kesalahan pemakaian tanda baca terdapat kesalahan pada daftar pustaka. Kesalahan pertama yaitu "Finoza, Lamudin. 2002.. Komposisi Bahasa Indonesia. Jakarta: Insan Mulia." Kesalahan pada penulisan tanda baca pada daftar pustaka terdapat pada penulisan tahun buku 2002. memakai tanda titik sebanyak dua kali seharusnya tanda titiknya hanya satu titik. Jadi penulisan yang benar dalam pemakaian tanda baca pada kata tahun adalah Finoza, Lamudin.

\section{Komposisi Bahasa Indonesia. Jakarta: Insan Mulia.}

Kesalahan berbahasa tersebut dapat dilihat pada rekapitulasi bagan data kesalahan berbahasa mahasiswa berikut: 
Tabel 1. Persentase kesalahan Ejaan pada Makalah Mahasiswa Prodi Teknik Mesin

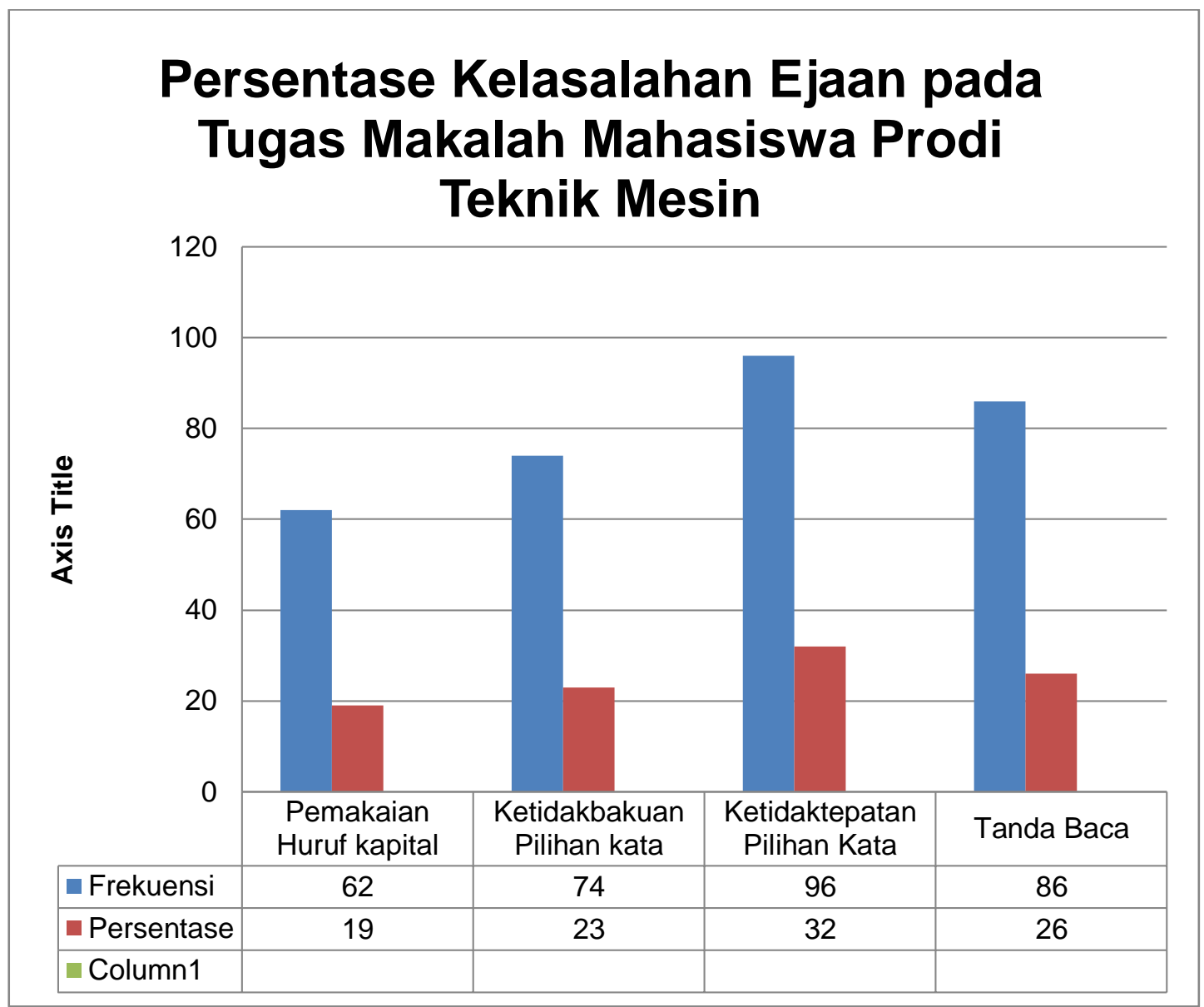

\section{E. SIMPULAN}

Berdasaarkan hasil penelitian menunjukkan bahwa masih ditemukan kesalahan ejaan pada pada makalah mahasiswa Prodi Pendidikan Teknik Mesin Universitas Muhammadiyah Tangerang. Jenis kesalahan ejaan yang sering dilakukan adalah kesalahan pemakaian huruf kapital, Ketidakbakuan pemilihan kata, (3) ketidaktepatan pemilihan kata, (4)penulisan tanda baca. Kesalahan ejaan pada makalah mahasiswa terletak pada kesalahan pemakaian huruf kapital ditemukan sebanyak 31, kesalahan terletak pada ketidakbakuan pilihan kata ditemukan sebanyak 37, kesalahan terletak pada ketidaktepatan pilihan kata ditemukian sebanyak 52, dan kesalahan terletak pada pemakaian tanda baca ditemukan sebanyak 43.

\section{F. DAFTAR PUSTAKA}

Ahmad dan Alek. 2016. Bahasa Indonesia untuk Perguruan Tinggi. Jakarta: Erlangga 
Dalman. 2018. Menulis Karya Ilmiah. Depok: Rajagrafindo Persada

Hermawan, Agus. 2019. Kesalahan Berbahasa dalam Makalah Mahasiswa Program Studi Pendidikan Bahasa Indonesia Tingkat II Semester 3 Universitas Nahdlatul Ulama Blitar Tahun 2019. Jurnal Pendidikan: Riset dan Konseptual. Vol 3 No 1 Januari 2019 PP 35-39

Kosasih. 2012. Dasar-Dasar Keterampilan Menulis. Bandung: Yrama Widya dan UPI

Moleong, J. L. (2005). Metodologi Penelitian Kualitatif. PT. Remaja Rosda Karya.

Turistiani, T. D. (2014). Fitur Kesalahan Penggunaan Ejaan yang Disempurnakan dalam Makalah Mahasiswa. Paramasastra, 1(1). 